\title{
Revista TextoPoético
}

Volume $9-2^{\circ}$ semestre de 2010

\section{Encontros com o texto poético}

(Editorial)

É com satisfação que a Coordenação do GT Teoria do Texto Poético (ANPOLL) vem anunciar a publicação do volume 9 ( $2^{\circ}$ semestre de 2010) da revista eletrônica TextoPoético, veículo que divulga resultados das pesquisas de membros do GT, bem como trabalhos de outros colaboradores não vinculados ao Grupo, mas que têm por objeto a poesia lírica e o texto poético.

Este número se reveste de singular importância, por dois motivos: em primeiro lugar, porque se abre com uma entrevista inédita do poeta Donizete Galvão (concedida a Antônio Donizeti Pires e Solange Fiuza Cardoso Yokozawa, coordenadores), onde ele aborda aspectos de sua vida e obra, de seu pensamento poético e da relação de amizade que manteve com a poeta Dora Ferreira da Silva, além de comentar seu último livro, $O$ homem inacabado (2010). O segundo motivo diz respeito ao fato de que este número da TextoPoético compreende parte considerável $(53,8 \%)$ dos 26 trabalhos apresentados por membros do GT durante o XXV ENANPOLL (Encontro Nacional da ANPOLL), ocorrido na UFMG, Belo Horizonte, entre os dias 1 e 3 de julho de 2010.

Por isso, a organização deste número da revista mantém (na medida do possível), se não a configuração das quatro sessões temáticas em que os ensaios foram comunicados, ao menos o espírito que as presidiu: assim, convidamos o leitor a considerar um primeiro bloco de textos em que a tônica é o Romantismo, o desabrochar da modernidade literária e o momento de consolidação da literatura brasileira, bem como o surgimento de uma poeta (no âmbito da literatura norte-americana) fundamental para as questões femininas (e feministas) na poesia, Emily Dickinson. Portanto, estão neste primeiro bloco os artigos de Alexandre Simões Pilati (UnB), "O desabrigo da 
subjetividade em dois poemas de Álvares de Azevedo"; o de Alcides Cardoso dos Santos (UNESP/Araraquara), "Emily Dickinson e a poesia de autoria feminina"; e o de Ilca Vieira de Oliveira (UNIMONTES), "Cecília Meireles e Castro Alves: a África como espaço do exílio e da liberdade": este faz a ponte entre Romantismo e Modernismo, no Brasil, ao evidenciar as imagens dúbias (de exílio e de liberdade) que a África suscitou no imaginário poético brasileiro.

O segundo grupo de textos, numa perspectiva ainda diacrônica, é voltado especificamente para a grande aventura modernista brasileira e compreende mais três artigos: "Diálogo poético", em que Rita de Cassi Pereira dos Santos (UnB) debruça-se sobre a última obra de Murilo Mendes, Convergência (1970), e estuda os modos compositivos e as relações intra e intertextuais suscitadas por esta; "Itinerário de Bandeira: nacional, regional e municipal", em que Éverton Barbosa Correia (UFMS/Três Lagoas) analisa vários poemas do bardo pernambucano, sempre à luz do "Itinerário de Pasárgada"; e "O fragmento poético em Cadernos de João, de Aníbal Machado", em que Adalberto Luis Vicente (UNESP/Araraquara), em boa hora, volta-se para o pouco estudado artista mineiro e ressalta a importância do fragmento poéticofilosófico (de origem romântica) na configuração da economia do livro de 1957.

O terceiro bloco compreende quatro estudos que se voltam mais especificamente para a ambígua produção poética dos anos de 1970, no Brasil, e merece a acurada atenção do leitor porque desvenda aspectos ricos e contraditórios dessa produção: o ensaio de Wilberth Salgueiro (UFES), “A poesia brasileira como testemunho da história (rastros de dor, traços de humor): a exemplo de Chacal", questiona as bases gerais, teóricas, da poesia de testemunho e esmera-se na análise de textos de Chacal, entre outros conhecidos "poetas marginais", ao enfatizar os dúbios aspectos de dor e humor, crítica e resistência, riso e ironia que tal poesia explorou. $\mathrm{O}$ artigo seguinte, "Melancolia a pino, impasse no locus tropical: notas sobre o poema 'Marinha', de Ruy Espinheira Filho", de Cristiano Augusto da Silva Jutgla (UESC), dialoga com o anterior porque o texto escolhido para análise (extraído do livro Heléboro, 1974) também é crítico à ditadura militar: não se tem, portanto, a ligação pelo viés da chamada "Poesia marginal", mas pela contundência temática, uma vez que a construção do poema de Espinheira Filho repercute ainda a alta tradição moderna da lírica. O ensaio de Paulo Andrade (UNESP/Assis), "O discurso da distopia na poesia brasileira contemporânea", 
estabelece interessantes relações com os dois artigos anteriores, pois crê que certa poesia brasileira dos anos 70 a esta parte (o autor cita Sebastião Uchoa Leite, José Paulo Paes, Armando Freitas Filho e Régis Bonvicino), pós-utópica (nos termos de Haroldo de Campos), apresenta um sujeito lírico que "dramatiza a descrença na eficácia do discurso poético" e nas soluções da vanguarda. O quarto artigo deste bloco, "A Orfeu, dois poemas da estrangeira", de Antônio Donizeti Pires (UNESP/Araraquara), talvez soe paradoxal e alienado em relação aos três anteriores, pois privilegia uma visão mais atemporal (metafísica? salvacionista?) de poesia lírica, onde é patente a negação indireta e a resistência simbólica da artista, por meio do resgate do mito (como diriam Adorno, Octavio Paz e Alfredo Bosi). É o que ressalta Pires ao assestar sua análise em dois poemas de Dora Ferreira da Silva dos anos 70 dedicados à figura mítica de Orfeu e à revisitação dos postulados órficos: são eles “Orfeu” (de Uma via de ver as coisas, 1973) e "Canto órfico" (só publicado em Poemas da estrangeira, 1995). Enfim, decida o leitor, mas leve em consideração as várias soluções diferentes encontradas pela poesia brasileira em um tempo insensível ao canto de Orfeu, bem como pese a multiplicidade de tendências individualistas e individualizantes que, a partir dos anos 70, vai se desenhando no panorama pós-utópico e pós-vanguardista da poesia brasileira.

Enfim, extremamente conectado ao anterior, o quarto bloco compreende a poesia brasileira "mais" contemporânea (dos anos 90/00), e abrange quatro estudos: o de Kelcilene Grácia-Rodrigues (UFMS/Três Lagoas), "O substrato do poético em "As lições de R.Q.', de Manoel de Barros", em que analisa detidamente o famoso metapoema de Livro sobre nada (1996); o de Fernando Fábio Fiorese Furtado (UFJF), ““Oceano coligido’: onde a linguagem faz questão”, em que o poeta-professor esmiúça com vagar o poema de seu conterrâneo e amigo Iacyr Anderson Freitas; enfim, o de Fabiane Renata Borsato (UNESP/Araraquara), "Memória e metalinguagem em Cais, de Alberto Martins" (em que estuda o livro de 2002 do poeta paulista), e o de Solange Fiuza Cardoso Yokozawa (UFG/Goiânia), "Geografia íntima das coisas: a poesia de Micheliny Verunschk”. O estudo de Yokozawa apresenta duas direções principais: primeiramente, uma estimulante reflexão geral sobre a lírica, de Hegel aos contemporâneos, em que as questões fulcrais "subjetivação; objetivação; poesia do eu; poesia das coisas; despersonalização; materialidade da linguagem" são discutidas a fim de se compreender a poesia moderna e a contemporânea; após, a estudiosa debruça-se 
sobre alguns poemas do livro de Micheliny Verunschk (Geografia íntima do deserto, 2003), ressaltando a voz original da jovem poeta de Pernambuco. As questões teóricas discutidas por Yokozawa embasam, mais imediatamente, os outros três textos alocados neste grupo, pois todos estão preocupados com aspectos materiais e metapoéticos da linguagem e com a construção do texto poético. Porém, a colocação estratégica do artigo de Yokozawa ao final deste volume da TextoPoético sinaliza para os problemas propriamente modernos da poesia lírica, cuja configuração (a melhor crítica o assinala) deve ser buscada nos primórdios dos Romantismos. Com isso, o ensaio da pesquisadora goiana ata-se, harmoniosa e sincronicamente, tanto aos textos de abertura deste número de nossa revista, quanto àqueles que, na sequência, enfocam a poesia modernista e contemporânea brasileira, evidenciando as preocupações que têm norteado, em grande parte, as pesquisas do GT Teoria do Texto Poético.

Araraquara/Goiânia, dezembro de 2010

Prof. Dr. Antônio Donizeti Pires

Profa. Dra. Solange Fiuza Cardoso Yokozawa

Coordenadores do GT Teoria do Texto Poético (ANPOLL) 